\title{
Effect of Different Dose of Nitrogen on Various Varieties of Potato in South Eastern Rajasthan
}

\author{
B.L. Nagar*, D.L. Yadav, R.S. Narolia and Rajendra Kumar Yadav
}

AICRP on Potato, Agricultural Research Station, Kota-324001 (Rajasthan), India

*Corresponding author

\section{A B S T R A C T}

Keywords

Agronomic use efficiency

(AUE), Net returns,

nitrogen, Potato, Yield,

Dry matter, AICRP-P-39

and KufriPukhraj

Article Info

Accepted:

10 July 2019

Available Online:

10 August 2019
The experiment was conducted at Agricultural Research Station, Kota during 2018-19 to evaluate potato cultivars viz. AICRP -P-39, KufriBahar and KufriPukhraj at four N levels $(0,80,160$ and $240 \mathrm{~kg} \mathrm{~N} / \mathrm{ha})$, to find out the $\mathrm{N}$ requirement and agronomic use efficiency of $\mathrm{N}$. Results revealed that KufriPukhraj recorded maximum yield, agronomic efficiency and net return at $160 \mathrm{~kg} / \mathrm{ha}$ of nitrogen followed by AICRP-P-39.KufriPukhraj proved to possess high tolerance to $\mathrm{N}$ stress and was the most nitrogen efficient variety followed by AICRP -P-39. This variety can be useful for resource poor farmers as this produces higher yield compared to other released varieties even at lower doses of $\mathrm{N}$.

\section{Introduction}

Potato plays a vital role in food security for ever increasing world population (Thiele et al., 2010; Scott and Sourez, 2012). It is highly capital and labour intensive crop (Kushwah and Singh, 2011). Presently, India is the second largest potato producer in the world. For achieving higher productivity, the use of nitrogenous fertilizers is increasing, which is leading to the increase in cost of production and also the environmental pollution. Potato is a very sensitive crop to nitrogen fertilization. Excess nitrogen may prolong the vegetative phase and thus, interfere with the initiation of tuberization, decreasing yield and dry matter accumulation in the tubers. On the other hand, a low nitrogen application rate may produce premature senescence in the plants due to early translocation of nitrogen from the leaves to the tubers (Saluzzo et al., 1999).

Central Potato Research Institute, Shimla (India) has developed a number of potato varieties for different agro-climatic conditions which vary in their response to nitrogen. Therefore, identification of nitrogen efficient varieties which produce higher yields per unit of nitrogen was required. Keeping this in view, the present study was undertaken to find out nitrogen requirement of the promising potato varieties and to work out their agronomic use efficiency (AUE) under Indo Gangetic plains of India. 


\section{Materials and Methods}

A field experiments was conducted at Agriculture Research Station Ummedganj, Kota, Research Farm with popular Potato cultivars AICRP-P-39. KufriPukhraj and K. Bahar. The soil of the experimental field was clay loam in texture with low organic matter (0.3\%), pH (7.54), available $\mathrm{N}(150 \mathrm{~kg} / \mathrm{ha})$, available $\mathrm{P}(45 \mathrm{~kg} / \mathrm{ha})$ and available $\mathrm{K}(351$ $\mathrm{kg} / \mathrm{ha}$ ). Treatments included combinations of eight varieties (AICRP -P-39, KufriBahar and KufriPukhraj) and four $\mathrm{N}$ levels $(0,80,160$ and $240 \mathrm{~kg} / \mathrm{ha}$ ), replicated three times in factorial randomized block design. Surface soil samples taken before planting of potato crop were analyzed for their physico-chemical properties employing standard procedures. Well sprouted seed tubers were planted in the $2^{\text {nd }}$ week of November. Half of the $\mathrm{N}$ was applied as Urea in side-band along with a uniform dose of $125 \mathrm{~kg} \mathrm{P} 2 \mathrm{O} 5 /$ ha through single super phosphate and $125 \mathrm{~kg} \mathrm{~K} 2 \mathrm{O} / \mathrm{ha}$ through muriate of potash at planting while the remaining $\mathrm{N}$ was applied through urea at 30 days after planting i.e. at the time of earthing up. Recommended package of practices were followed for raising the crop, haulms were cut at 100 days after planting and harvesting was done 15 days later. In situ green manuring with dhaincha (Sesbania aculeata) was buried in the soil before planting of potato. Agronomic use efficiency (AUE) measures the amount of tuber yield produced per unit of nutrient supplied (soil supply + fertilizer applied) (Fageria et al., 2008). Nutrient use efficiency viz. agronomic efficiency was computed using following formula.

(TY)

$$
\text { AUE of N = ---------- }
$$

Where,

TY, SN and QF are tuber yield in a particular treatment $(\mathrm{kg} / \mathrm{ha})$, soil available $\mathrm{N}(\mathrm{kg} / \mathrm{ha})$ and quantity of fertilizer $\mathrm{N}$ applied ( $\mathrm{kg} / \mathrm{ha})$, respectively.

Net return for all the varieties was calculated taking nitrogen price $5.77 \mathrm{Rs} . / \mathrm{kg}$ for urea, SSP 4.8Rs./kg and MOP 13 Rs. $/ \mathrm{kg}$ and potato price as $6000 / \mathrm{t}$.

\section{Results and Discussion}

Marketable yield, dry matter and tuber yield were significantly influenced by levels of $\mathrm{N}$ and potato varieties (Table 1). Maximum tuber yield, which was significantly higher over other varieties, was obtained from $160 \mathrm{~kg} / \mathrm{ha}$ of nitrogen on KufriPukhraj (22.83 t/ ha) followed by AICRP -P-39 (21.68 t/ ha). While, minimum yield was observed in KufriBahar (19.72 t/ ha). The interaction between $\mathrm{N}$ levels and varieties was found significant. KufriPukhraj produced the highest tuber yield at $160 \mathrm{~kg} / \mathrm{ha}$ of $\mathrm{N}$ as compared to other varieties. However, the response to $\mathrm{N}$ application rate decreased significantly in all varieties upto the highest levels of $\mathrm{N}(240 \mathrm{~kg} /$ ha).Tuber yield response at $80 \mathrm{~kg} \mathrm{~N} /$ ha was higher in AICRP -P-39. Among the different nitrogen doses $(80,160$ and $240 \mathrm{~kg} / \mathrm{ha}$ ), maximum $\mathrm{N}$ response in terms of yield was observed at $160 \mathrm{~kg} / \mathrm{ha}$. Duynisveld et al., (1988) and Sharifi et al., (2007) have also reported that different cultivars behave differently in terms of yield and bulking rate, to the applied nitrogen. Agronomic use efficiency of nitrogen Agronomic use efficiency (AUE) of nitrogen by various potato varieties calculated as $\mathrm{kg}$ tuber produced per kg N supply (soil + fertilizer) showed considerable variation (Table 2). Results showed that KufriPukhraj was the most nitrogen efficient cultivar followed by AICRP -P-39. The efficient cultivars gave higher tuber yield under nutrient stress (i.e. with less dose of $\mathrm{N}$ ) than less efficient cultivars. The main reason for higher nitrogen efficiency in the presence or absence of $\mathrm{N}$ was the capacity of a genotype to use/ absorb more $\mathrm{N}$ per unit from soil (Trehan, 2009). 


\section{Net returns}

Net returns increased with increase in $\mathrm{N}$ levels (Table 2). KufriPukhraj gave maximum returns at $160 \mathrm{~kg} / \mathrm{ha}$ of nitrogen net return of 97403/ha followed by KufriPukhraj (93383/ha). KufriPukhraj followed by KufriPukhraj proved to be the best variety as far as yield, AUE of $\mathrm{N}$ and net returns were concerned.

Total tuber yield of these two varieties obtained higher at $160 \mathrm{~kg} \mathrm{~N} / \mathrm{ha}$. The benefit: cost ratio (2.57) was highest in the KufriPukhraj followed by AICRP-P-39 (2.5).

Table.1 Effect of various dose of Nitrogen on different varieties of potato

\begin{tabular}{|c|c|c|c|c|c|}
\hline Variety & $\%$ emergence & $\begin{array}{l}\text { Foliage } \\
\text { Senescence (\%) }\end{array}$ & $\begin{array}{l}\text { Marketable } \\
\text { yield (t/ha) }\end{array}$ & $\begin{array}{l}\text { Total yield } \\
\text { (t/ha) }\end{array}$ & $\begin{array}{l}\text { Tuber dry } \\
\text { matter }(\%)\end{array}$ \\
\hline AICRP-P-39 & 94.91 & 79.02 & 20.02 & 21.68 & 18.55 \\
\hline K. Bahar & 95.33 & 83.82 & 18.05 & 19.72 & 22.70 \\
\hline K. Pukhraj & 95.10 & 77.49 & 21.17 & 22.83 & 19.56 \\
\hline CD & 0.18 & 1.93 & 1.38 & 1.37 & 0.17 \\
\hline SE(M) & 0.06 & 0.66 & 0.47 & 0.47 & 0.06 \\
\hline \multicolumn{6}{|l|}{ Nitrogen level kg/ha. } \\
\hline Control & 94.07 & 87.60 & 14.25 & 15.91 & 19.83 \\
\hline $80 \mathrm{~N}$ kg/ha & 94.98 & 79.43 & 20.65 & 22.32 & 20.13 \\
\hline $\begin{array}{l}3 . \\
60 \mathrm{~N} k / \mathrm{ha}\end{array}$ & 95.57 & 74.86 & 23.02 & 24.69 & 20.47 \\
\hline $240 \mathrm{~N} \mathrm{~kg} / \mathrm{ha}$ & 95.83 & 78.54 & 21.06 & 22.73 & 20.64 \\
\hline CD & 0.20 & 2.23 & 1.59 & 1.59 & 0.20 \\
\hline SE(M) & .07 & 0.76 & 0.54 & 0.54 & 0.07 \\
\hline
\end{tabular}

Table.2 Net returns (Rs/ha) from different potato cultivars at different $\mathrm{N}$ levels

\begin{tabular}{|c|c|c|c|c|c|c|c|c|c|}
\hline \multirow[t]{2}{*}{ Treatments } & \multirow{2}{*}{$\begin{array}{l}\text { Yield } \\
\text { (t/ha) }\end{array}$} & \multicolumn{3}{|c|}{ Cost of cultivation (Rs/ha) } & \multicolumn{2}{|c|}{ Cost (Rs/ha) } & \multirow{2}{*}{$\begin{array}{c}\text { Sale price } \\
\text { (Rs/t) }\end{array}$} & \multirow{2}{*}{$\begin{array}{c}\text { Net } \\
\text { returns* } \\
\text { (Rs/ha) }\end{array}$} & \multirow{2}{*}{$\begin{array}{l}\text { B:C } \\
\text { ratio }\end{array}$} \\
\hline & & Seed & Fertilizer & Cultivation & Inputs & Produce & & & \\
\hline $\mathbf{V}_{1} \mathbf{N}_{\mathbf{0}}$ & 14.78 & 24000 & 6458 & 29675 & 60133 & 88680 & 6000 & 28547 & 1.47 \\
\hline $\mathbf{V}_{2} \mathbf{N}_{0}$ & 15.74 & 24000 & 6458 & 29675 & 60133 & 94440 & 6000 & 34307 & 1.57 \\
\hline $\mathbf{V}_{3} \mathbf{N}_{0}$ & 17.22 & 24000 & 6458 & 29675 & 60133 & 103320 & 6000 & 43187 & 1.72 \\
\hline$V_{1} N_{1}$ & 23.51 & 24000 & 7460 & 29675 & 61135 & 141060 & 6000 & 79925 & 2.31 \\
\hline $\mathrm{V}_{2} \mathrm{~N}_{1}$ & 20.66 & 24000 & 7460 & 29675 & 61135 & 123960 & 6000 & 62825 & 2.03 \\
\hline $\mathrm{V}_{3} \mathrm{~N}_{1}$ & 22.78 & 24000 & 7460 & 29675 & 61135 & 136680 & 6000 & 75545 & 2.24 \\
\hline $\mathbf{V}_{1} \mathbf{N}_{2}$ & 25.92 & 24000 & 8462 & 29675 & 62137 & 155520 & 6000 & 93383 & 2.50 \\
\hline $\mathbf{V}_{2} \mathbf{N}_{2}$ & 21.56 & 24000 & 8462 & 29675 & 62137 & 129360 & 6000 & 67223 & 2.08 \\
\hline $\mathbf{V}_{3} \mathbf{N}_{2}$ & 26.59 & 24000 & 8462 & 29675 & 62137 & 159540 & 6000 & 97403 & 2.57 \\
\hline $\mathrm{V}_{1} \mathrm{~N}_{3}$ & 22.52 & 24000 & 9464 & 29675 & 63139 & 135120 & 6000 & 71981 & 2.14 \\
\hline $\mathbf{V}_{2} \mathbf{N}_{3}$ & 20.92 & 24000 & 9464 & 29675 & 63139 & 125520 & 6000 & 62381 & 1.99 \\
\hline $\mathbf{V}_{3} \mathbf{N}_{3}$ & 24.74 & 24000 & 9464 & 29675 & 63139 & 148440 & 6000 & 85301 & 2.35 \\
\hline
\end{tabular}

Note:

V1AICRP-P-39, V2= K.Bahar, V3=K.Pukhraj

$\mathrm{N} 0=$ control, N1=80kg, N2=160 and N3=240kg/ha Nitrogen 
Fig.1 Effect of different nitrogen dose on various potato varieties

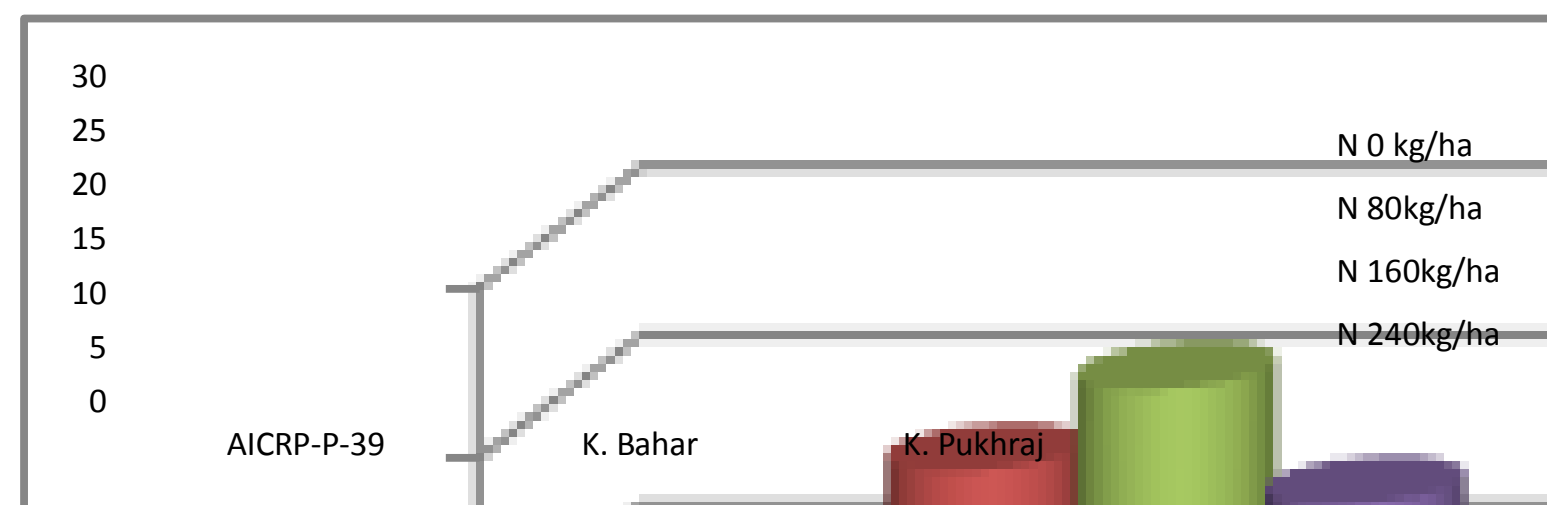

Fig.2 B:C Ratio of different nitrogen dose on various varieties of potato

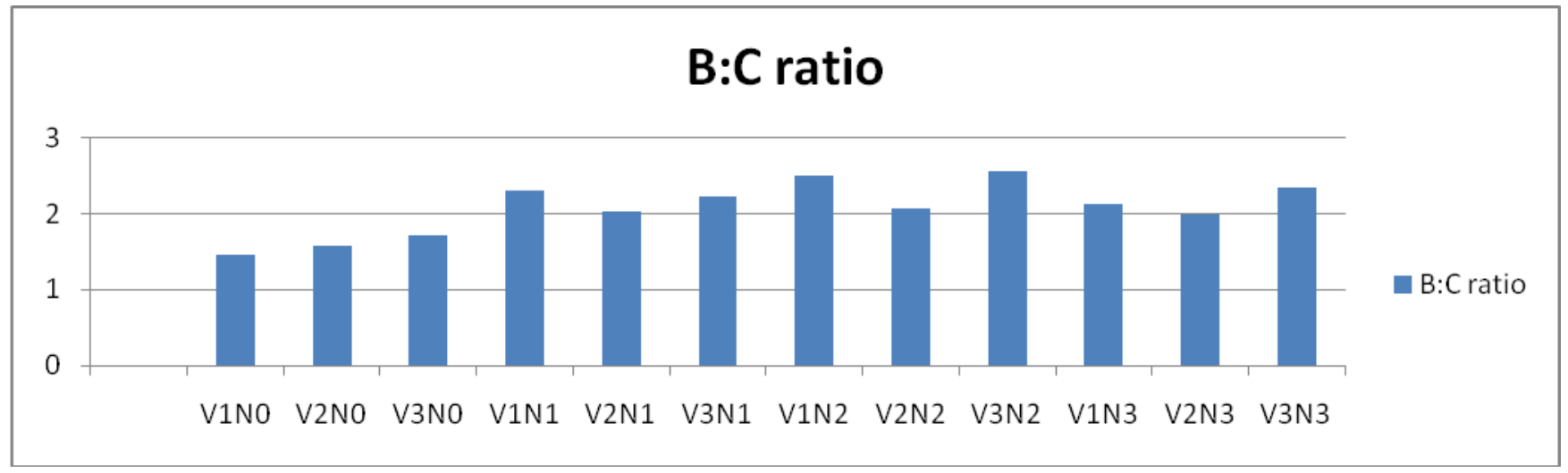

\section{Aerial view of experiment}

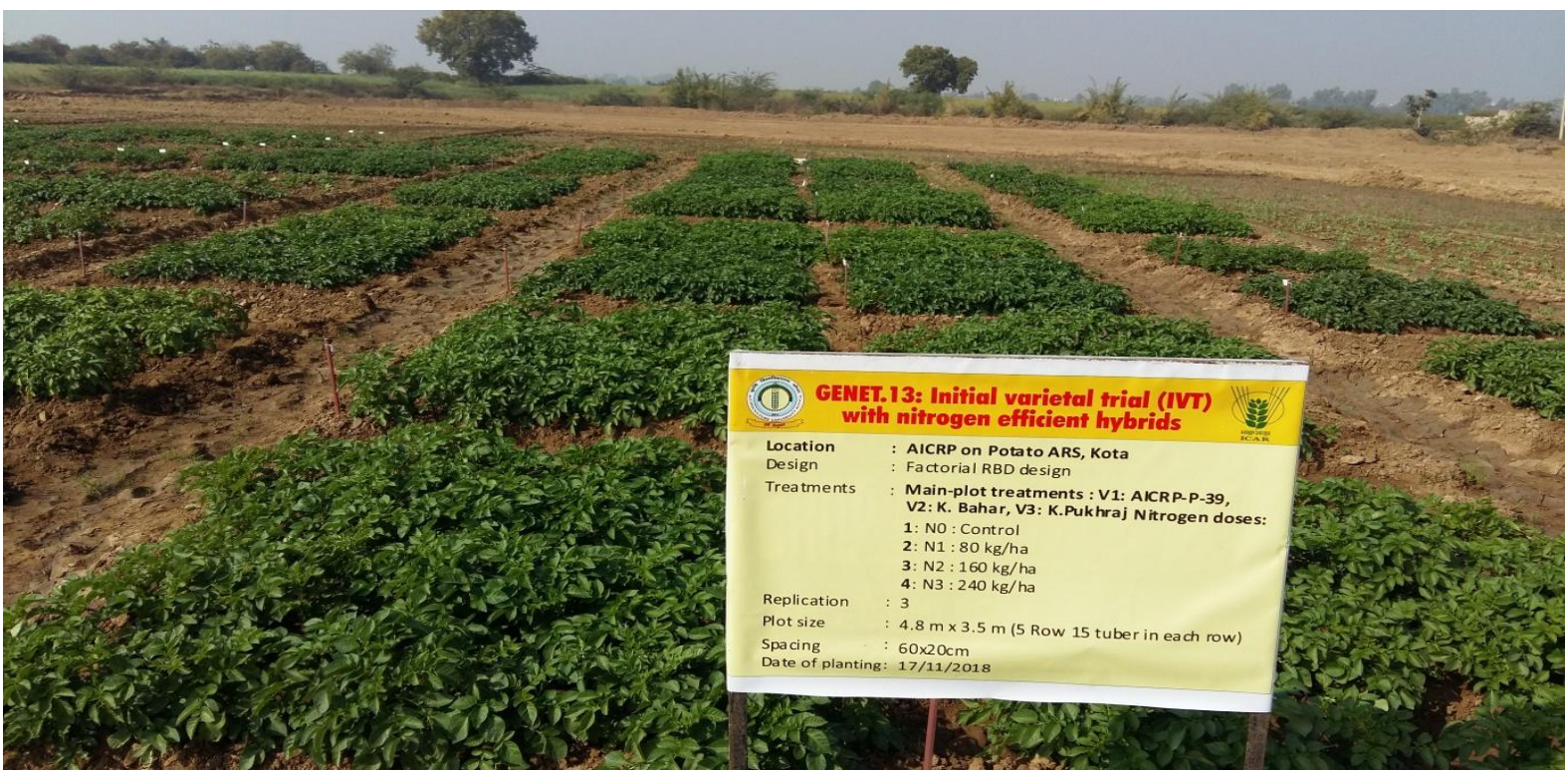


Treatment wise photos of experiment

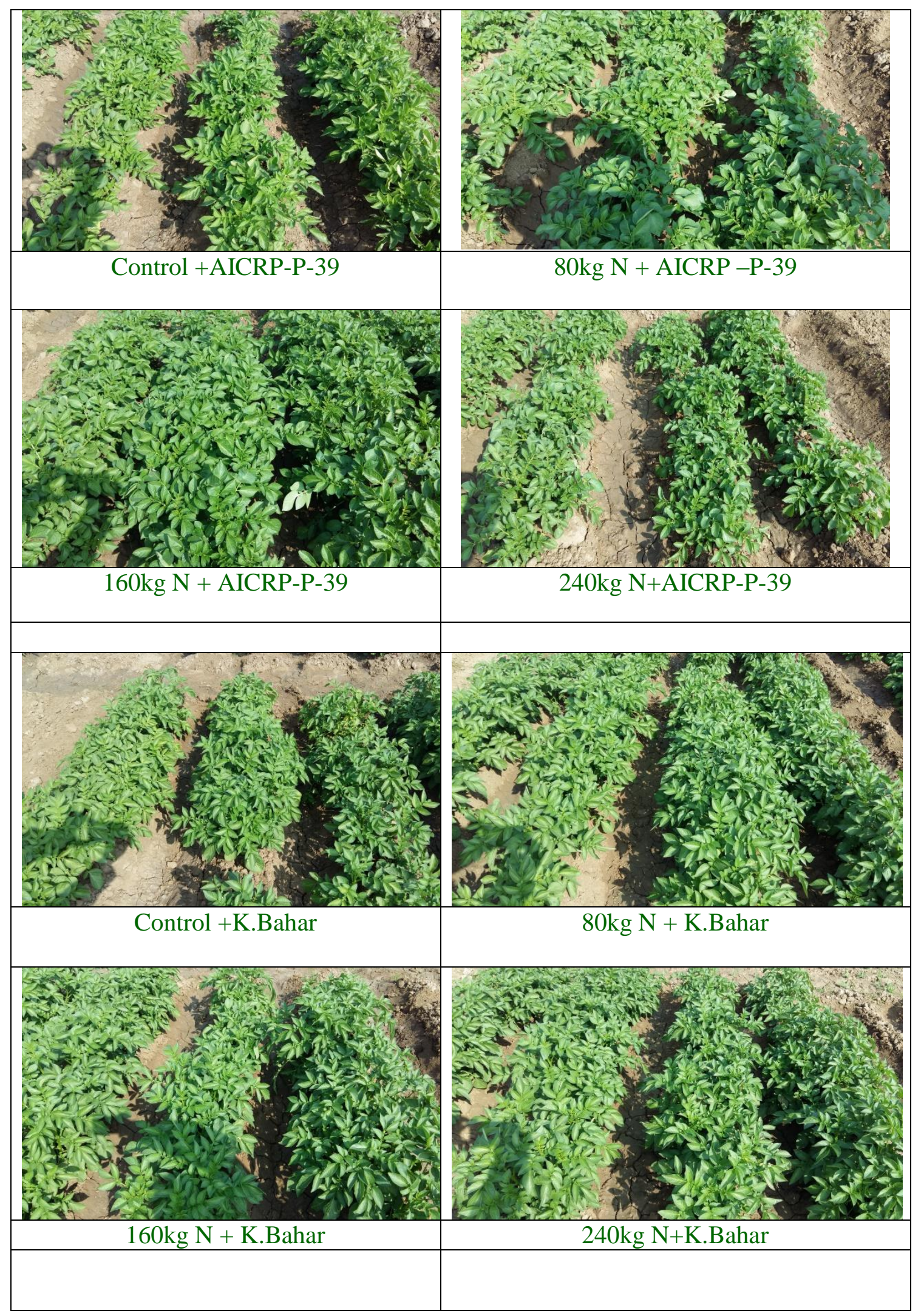




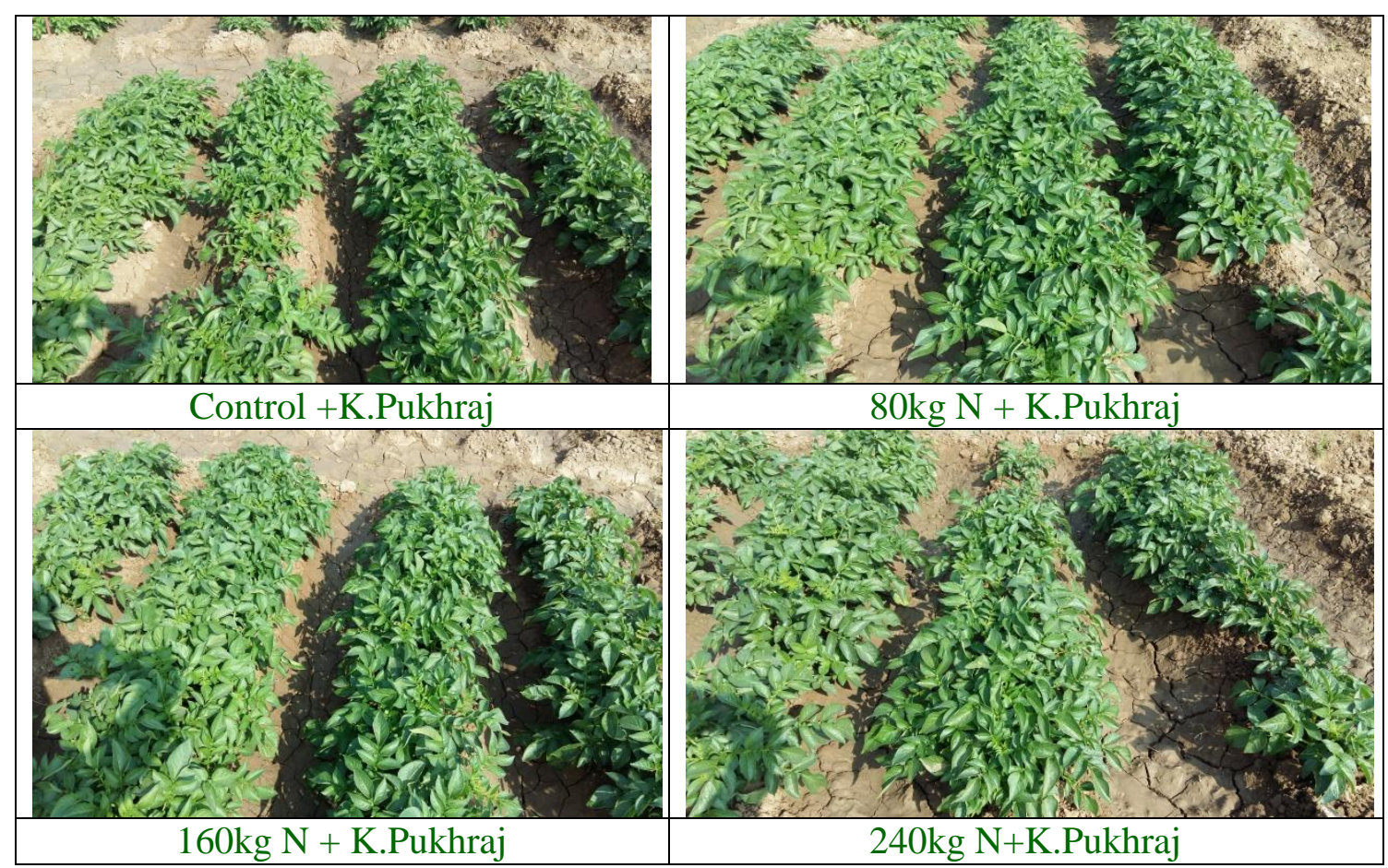

Present study concluded that potato cultivars showed wide variation in agronomic use efficiency (AUE of $\mathrm{N}$ ) with respect to nitrogen. Potato cultivar KufriPukhraj was the highest yielder and most $\mathrm{N}$ efficient variety followed by AICRP-P-39. Nitrogen dose was significantly observed in various varieties as well as higher dose of Nitrogen response in decrease tuber yield.

\section{Acknowledgements}

The authors are grateful to the Director, ICAR, CPRI, Shimla, ZDR and Director Research, Agriculture University, Kota for providing necessary facilities under the institute project.

\section{References}

Duynisveld WHM, Strebel O and Bottcher J (1988). Are nitrate leaching from arable land and nitrate pollution of ground water avoidable. Ecol Bull 39:116-25

Fageria NK, Baligar, VC and Li YC (2008). The role of nutrient efficient plants in improving crop yields in the twenty first century. J Plant Nutr 31: 1121-57

Kleinkopf G, Westermann DT and Dwelle RB (1981). Dry matter production and nitrogen utilization by six potato cultivars. Agron J 73: 799-02

Kushwah VS and Singh SP (2011). Relative performance of low input and high input technology for potato production in India. Potato J 38(1): 56-60

Saluzzo JA, Echeverr'1a HE, Andrade FH and Huarte M (1999). Nitrogen nutrition of potato cultivars differing in maturity. $\mathbf{J}$ Agron Crop Sci 183(3): 157-65

Scott GJ and Suarez V (2011). Growth rates for potato in India and their implications for industry. Potato J 36(3-4): 121-35

Scott GJ and Suarez V (2012). The rise of Asia as the centre of global potato production and some implications for industry. Potato J 39(3-4): 1-22

Sharifi M, Bernie JZ and Coleman W (2007). Screening for nitrogen-use efficiency in potato with a recirculating hydroponic system. Commun Soil Sci Plant 38: 359-70 
Thiele $\mathrm{G}$, Theisen $\mathrm{K}$, Bonierbale $\mathrm{M}$ and Walker T (2010). Targeting the poor and hungry with potato science. Potato $\mathrm{J}$ 37(3-4): $75-86$
Trehan SP (2009). Improving nutrient use efficiency by exploiting genetic diversity of potato. Potato J 36(3-4): $121-35$.

\section{How to cite this article:}

Nagar, B.L., D.L. Yadav, R.S. Narolia and Rajendra Kumar Yadav. 2019. Effect of Different Dose of Nitrogen on Various Varieties of Potato in South Eastern Rajasthan. Int.J.Curr.Microbiol.App.Sci. 8(08): 1081-1087. doi: https://doi.org/10.20546/ijcmas.2019.808.126 